\title{
"You see how good-looking Lee Ann is!" Establishing field relations through gendered and racialised bodily practices
}

\author{
Marlene Spanger
}

\begin{abstract}
By investigating the case of female Thai migrants selling sexual services in Denmark, I argue that 'the victim' versus 'the empowered subject' is an undesirable binary for analysing how female migrants perform gendered subject positions in their everyday life. The article suggests a poststructuralist feminist perspective, arguing that looks and bodily practices, based on different constellations of gender and sexuality and race and nationality, are important for the research situation. Bringing in two different examples, the article analyses the field relations, and the implied power relations, - between the researcher(s) and the studied subjects that are constituted through gender, sexuality, race and nationality. These relations form the premises for producing material.
\end{abstract}

Key words: Fieldwork, subject positions, gender, race, migration, sex work

Please cite this article as: Spanger, M. (2012). "You see how good-looking Lee Ann is!" Establishing field relation through gendered and racialised bodily practices, Qualitative Studies, 3(2): 150-162.

\section{Introduction}

This article ${ }^{1}$ investigates how the subjects' looks and bodily participation in the process of fieldwork affect the interaction between the researchers and the studied subjects in particular situations. Thus, the purpose is to render visible the process of producing material through participant observations and interviews among Thai migrants selling sexual services in Denmark. In order to investigate how the looks of the subjects is crucial in producing material, I focus on how different intersecting constellations of gender, race, nationality and sexuality constitute hierarchies that are established during fieldwork.

Migrants selling sexual services have been articulated as 'victims' (Aoyama, 2009; Davidson, 1998), 'modern female slaves' versus 'empowered women' (Chapkis, 1997; Pheterson, 1996) or 'entrepreneurs'. Despite differences in the views on these female migrants, the conceptualisations all spring from a dichotomous thinking that refers to a question of victimisation versus agency, trafficking versus labour migration. This conceptual framework was established during the 1980s and has dominated the international literature on commercial sex and human trafficking, as well as the political debates on human trafficking, migrantrelated prostitution and global sex work (Kempadoo et al., 2005; Doezema, 1998; Agustín, 2005; Sanders, 2006; Spanger 2010). Likewise, in the context of social work in Denmark, migrant sex workers are predominantly identified through the discourse of human trafficking and/or viewed as social problems (Spanger, 2011). The disadvantage of such a dichotomy is the production of stereotypes of 'good' or 'bad' women, which does not leave room for the highly complex narratives of the heterogeneous social group of migrants selling sexual services (Testai, 2008), in this case, female Thai migrants. Thus, selling sex is commonly treated and perceived as

\footnotetext{
1 The article is based on my PhD thesis Spanger, M. (2010). Destabilising Sex Work E Intimacy? Gender Performances of Female Thai Migrants Selling Sex in Denmark. Department of Society \& Globalisation, Roskilde University.
} 
an identity encumbered with prejudice and stereotypes rather than merely an incomegenerating activity (Shaver, 2005; Pheterson, 1996). In a present Danish context the term 'prostitution' and 'prostitute' spring from a social policy discourse (Spanger, 2011). However, 'sex work' and 'sex worker' are not predominantly terms that are used within social work. These terms spring from the professional organisations that represent women, who identify themselves as sex workers. Moreover, the Danish concept of 'sex work' and 'sex worker' derive from the international debate on 'prostitution' versus 'sex work' that has taken place since the 1970s (Kempadoo et al, 2005; Doezema, 1998).

During recent years human trafficking and migrants selling sex have been hot issues in the Danish media. Consequently, within a Danish context, the establishment of the figure 'The Thai Woman' is closely linked to the whore stigma, always willing to sell sex, connoting, on the one hand, a victim of patriarchy and, on the other hand, sexual promiscuity (Petersen, 2009). These stereotypes affect Thai migrants in different ways (see Spanger 2010). However, the central paradox is the following: on the one hand, earning money through prostitution is a well-known practice within the Thai community. On the other hand, this practice is socially taboo in Denmark. Furthermore, Thai migrants in general have to struggle with the stereotypical picture of all Thais as prostitutes.

Questioning the use and the reproduction of sex work and prostitution discourses that constitute the dichotomous fixed categories of 'the victimised prostitute' versus 'the empowered sex worker', the article aims for contributing to a more complex methodological approach within the literature on transnational prostitution and human trafficking. To do so, I draw on poststructuralist feminist studies (Lather, 2000; Lykke, 2008) arguing that the material is a result of power relations depending on the subjects' bodily practices and appearances. I argue that in the study of Thai migrants selling sexual services (see later) the researchers' bodily practices and looks affected the power relations that were established in our interaction with the studied people. In particular, notions of gender, race, sexuality and nationality came into play as categories that lay the ground for our relations and interactions with the studied people. As the article will show, the different kinds of constellations and entrances resulted in multiple narratives of female Thai migrants selling sex. Bringing in difference as a premise for producing material, this article investigates the question: how do look and bodily practices become important in the research?

The first section presents my ethnographic fieldwork, consisting of participant observations and interviews, day and night among Thai migrants selling sexual services in Denmark. The second section discusses positioning in fieldwork. The subsequent sections analyse two examples from my fieldwork, demonstrating how looks and bodily practices, based on different complex constellations of gender, race, sexuality and nationality, establish powerfulness and powerlessness, as well as difference and sameness between the researcher(s) and the researched subjects.

\section{Ethnographic fieldwork among Thai migrants selling sex}

This article springs from a study that aimed to investigate how the Danish policy field of prostitution is linked to the way in which female Thai migrants selling sex in Denmark destabilise sex work and intimacy through their gendered performances. The study asks the following question: how do female Thai migrants selling sex in Denmark destabilise and reproduce the policy category of 'sex work' through their way of performing gender? 
From September 2005 to April 2006 I conducted ethnographic fieldwork (Hasse, 2000), in terms of participant observations and interviews, by once or twice a week following a counselling programme targeting migrants selling sexual services, participating in a coordinating meeting for all the actors involved in the counselling programme, and participating in meetings with social workers and consultants who were connected to the first action plan from 2001 of the government. In addition, I compiled policy documents that related to the policy issue of prostitution, migration and human trafficking. Moreover, I visited massage parlours, strip bars and places and events that female Thai migrant sex workers visit or participate in (Thai concerts, annual Thai festivals arranged by one of the temples, a Thai super market, Thai clubs and bars, one of the Buddhist temples) I realised that the female Thai sex workers are not an isolated social group within this migrant community. ${ }^{2}$

Inspired by Nencel's (2001) ethnographic fieldwork on women selling sex in Lima, I structured my participant observations and interviews in a day and night rhythm. Visiting bars and participating in different events in the Thai migrant community at night, and following the counselling programme during the daytime and visiting massage parlours gave me an opportunity to meet Thai migrant sex workers in different everyday situations and settings that resulted in different kinds of narratives. Moreover, I interviewed the migrants whenever they had time; be it day or night. Together, the female Thai migrants' narratives draw a complex picture of their everyday lives.

I asked specific questions relating to their job such as working hours and conditions in order to avoid reproducing the dichotomous thinking. I opened up the interview by introducing myself and underscoring that I was a researcher studying Thais everyday lives in Denmark and how they earned money. Often children were a common theme since the majority of the women were mothers. Having these considerations in my mind and being aware of the fact that sex work is a sensitive research field, dominated by prejudices and a stigmatisation of female sex

2 I have undertaken 14 interviews with Thai migrants all defining themselves as female Thai migrants. Ten are biologically born women, three are transgendered persons (male to female) and one is a cross-dresser. All the female Thai migrants were between the ages of 25 to 40 years old and had acquired residence permits through marriage. Some have permanent residence permits, others were applying for residence permits, and others could not yet apply at the time I interviewed them due to the Danish legislation on family reunification. Some of the interviewees were divorced, others married, and one was a widow. All have sold or sell sexual services full time or part time in Denmark at massage parlours or at bars as dancers and hostesses. Besides interviewing female Thai migrant sex workers I have conducted interviews with seven key persons from the Thai migrant community: six shop/restaurant owners and one bartender who have close contact to Thai migrant sex workers. Interviewing those persons, who are not in the sex industry but who are key persons in the Thai community, is relevant when gaining knowledge of the Thai community from other perspectives. Such a perspective contributes to a wider understanding of the female Thai migrants' everyday lives, given that they see themselves as a part of the Thai migrant community in Denmark. Moreover, I conducted interviews with eight experts within the field of trafficking and prostitution (two representatives from the police, four social workers and two administrators) who all have contact to or knowledge about Thai migrant sex workers. They informed me about female Thai migrant sex workers in Denmark, how they approach and view them. All interviews were recorded and lasted from one to two hours. 
workers, I never used the word 'prostitute/prostitution', 'victim', 'sex worker/sex work', 'empowerment' unless my informants introduced the concepts themselves in our conversations.

Field relations are not always created simply between the researcher and the studied people. In this study, I employed two different gatekeepers (Sanghera et al, 2008; Reeves, 2010) positioned as a professional female social worker and an informal male 'semi-insider' (a student), who also functioned as my research assistant. By using two different gatekeepers I was quite aware of the fact that they represented different approaches to, and views on, migrants selling sex, which influenced the process of gaining access to the Thai migrants' stories. Nonetheless, this article will only focus on the unfolding of field relations in situations where the informal male 'semiinsider' Niels came along with me on field work. Reflecting on, how I, as researcher, and my gatekeeper, are positioned in relation to the Thai migrants selling sexual services helps me understand the complex premises for producing material within studies of transnational prostitution.

\section{Positioning in field work}

A number of studies on method argue that social relations, created during the process of fieldwork, are based on the intersections of multiple categories like gender, race and sexuality (Lykke, 2008; Archer, 2002; Yuval-Davis, 2006). Archer (2002) stresses that the ways in which the researcher and the interviewees perform gender and race during fieldwork imply 'difference' as well as 'sameness' that reflect power relations created during the interaction between the researcher and the interviewees. Inspired by Archer I pay attention to difference and the performance of gender and race in order to investigate how access is formed as a result of highly complex power relations between the researcher, the research assistant and the researched. I obtained access to the migrants selling sexual services in different locations: a social counselling programme targeting migrant sex workers as well as massage parlours and bars. Conducting fieldwork in different locations and situations has resulted in different narratives. Besides focusing on gender and race, I also include sexuality and nationality as categories that constitute difference and similarities. Altogether, this leads to rather multifaceted empirical material in terms of narratives on gendered sex work.

With reference to Haraway's (1991) idea of being deliberate about one's own social positions, seeing that a social position can never be neutral, I argue that the construction of the subject positions of the male research assistant, the female Thai migrants selling sex, as well as my own subject position during fieldwork derive from the intersection of a number of categories. Thus, the article is inspired by an intersectional methodology (Phoenix, 2006; Spanger 2010). Drawing on Butler (1990), the construction of the subject is a process that relies on performance reiterating norms, practices, appearances. Butler calls this process subjection, talking about becoming a subject, which signifies a process of power that subordinates the individual. At the same time, power provides for the existence of the subject, given that power forms the subject (see also Jensen, this issue). As the article will show, the constitution and negotiation of my subject position within this space of commercial sex created possibilities and limitations with regard to investigating the ways in which the female Thai migrants perform femininity.

Employing a poststructuralist feminist perspective the material is understood as being produced through active interchanges of meanings between the implied subjects (see e.g. Søndergaard, 2002; Haavind, 2000; Lather, 1986, 2000). I argue that the researcher must be aware of the ongoing positioning and how we constantly negotiate possible subject positions that imply power relations. For example, the subject positions of 'academic middle-class Korean 
adoptee woman', 'the third-world woman selling sex in Denmark' or 'the white young academic male' are all grounded in the categories of gender, sexuality, race, class, age, and they affect the complex power relations between the researcher, the studied subjects and eventually the gatekeeper.

The research assistant Niels studied Thai culture and language, primarily focusing on Thailand. Thus, our respective focus was displaced, and a battle or competition about knowledge did not determine our relation and the way in which our positions were established within the field. As a point of departure, I hired Niels and developed the framework for visiting bars at night, while at the same time being sensitive to Niels' suggestions and ideas, given that he knew a number of Thais in Denmark. Moreover, having an academic background made it easier for us to discuss our positions at the bars and our encounters with the female Thais selling sex and the Danish male guests with regard to what to look for, whom we came in contact with and what we talked about with the Danish male guests and the female Thai migrants. Thus, Niels functioned as an informal semi-inside gatekeeper, since he speaks Thai and has contact to key persons within the Thai migrant community in Denmark and has insight into the Thai culture in Denmark as well as in Thailand. He introduced me to places and people in the migrant community. In particular, we visited bars together at night. Entering the bars, Niels and I represented a heterosexual couple. At first sight we were intelligible, so to say. With our looks, me representing an Asian woman and Niels representing a white Danish man, we matched the predominantly racialised gender pattern; Asian women from Thailand and Danish white men. This was also a part of my strategy during fieldwork at the bars. At the same time, we were positioned as an 'odd' couple since we were wearing everyday clothing, attending together, but did not signal that we were a couple (holding hands, kissing), and at the same time I look Asian, but speak Danish, while Niels looks Danish, but speaks Thai fluently. The female Thais became somewhat confused and had difficulties positioning us as respectively costumer and sex worker. Sometimes the staff and the male guest positioned us as journalists or police officers. At the bars it was predominantly Niels who established contact to the female sex workers and not me. Considering him a young white heterosexual man, the female Thai migrants selling sex were curious about him: why he spoke Thai, and at the same time he was not interested in their sexual services, but in their private lives. If there were no potential clients at the bars, some of them talked to him. Quite quickly the Thai migrants realised that Niels was not a potential client. Rather, they found him interesting given that he represented a different masculinity that challenged the stereotypical notion of the white Danish man within this location.

Conversely, the men at the bar sometimes made contact with me, often positioning me as one of the 'Thai or Asian women'. Quite aware of how the intersection of the categories of race and gender could position me as sex worker from the male customers' gaze, I was calculatedly not wearing sexy or 'provocative' clothes during my visits at the bars at night, but instead ordinary jeans and a black or grey sweater with a polo neck, intending to perform 'another' femininity. By doing so, I deliberately tried to distance myself from the subject position of sex worker. Rather, I attempted to establish the subject position of researcher. Nonetheless, when the men addressed me, sexual undertones were in play. I found this rather unpleasant, given that such an attitude positioned me as a sex object, which I viewed as an inferior position. Being within the space of commercial sex and seen from my position, (that of a feminist researcher), their gaze on me and how they started a conversation with me reproduced discriminating and sexist stereotypical notions of what Davidson and Taylor (1999: 38) call "Western sex tourists' fantasies of 'docile' and 'willing' Asian women". When they tried to flirt with me I rejected 
them. Nevertheless, some of the men still told me about their relationship to female Thai migrants or their views on Thailand. During such conversations, some of the men positioned themselves as victims telling me how the female Thai migrants took advantage of their love and money. Suddenly, the women were not positions as 'docile Asian women', but rather as 'sly and heartless'. Thus, for me it was a balancing act to get insights about female Thai migrants selling sexual services, and at the same time not being exposed to sexualised racism articulated by the Danish men.

Representing different subject positions - brown (Asian) female academic and a white male academic - and talking to different subjects representing brown (Asian) female migrant sex workers and white Danish male guests, Niels and I had access to rather different narratives within the space of commercial sex. These different narratives demonstrate the complexity of how the Thai migrant selling sexual services may be positioned, and this complexity, I argue disrupts the dichotomy of 'the victim' versus 'the empowered subject'.

At the bars, Niels and I were looking at how the Danish male guests and the female Thai migrant sex workers interacted and created or did not create relations, or tried to establish contact. I observed how some of the female Thais were business-like, aggressive or friendly towards the male clients, what kind of clothes the female Thais wore, who they addressed, and how they gesticulated. Such superficial appearances display how gender is performed, and how different sexual encounters are established. I also had informal conversations with Thai female migrant sex workers at bars or at massage parlours, and with male Danes at bars. In particular, the informal talks at the bars with female Thai sex workers were undertaken by Niels. The 'heterosexual liaison' as the underlying norm at the bar, and speaking Thai, became his way of getting them to talk. In contrast, the female Thai migrants had no particular interest in talking to me at the bars ${ }^{3}$, but the male guests were very much interested in talking to me. Thus, our way of performing gender and sexuality created conditions for producing material at the bars. These observations and interviews form the basis of my analysis of gender hierarchies between the different social groups of female Thai migrant sex workers, be it female-born subjects, transgendered subjects (m-t-f) or cross-dressers. Such premises for producing material were somewhat different from the participant observations during the daytime at the massage parlours or at the counselling programme together with the other gatekeeper, the professional female social worker. In this way, I acquired different forms of access to the sensitive narratives told by the Thai migrants selling sexual services.

The following two examples spring from my fieldwork. They demonstrate how looks became important in different research situations. I use them to analyse how difference, sameness and power relations were constituted through the different constellations of gender, sexuality, race and nationality as premises for producing material.

\footnotetext{
${ }^{3}$ A number of methodological feminist studies argue that the same gender of the researcher and the studied subjects is an advantage in the interview situation and during fieldwork, based on the idea that the category of woman establishes a common understanding (Archer, 2002). My experiences, on the contrary, demonstrate that the intersecting categories of gender, race, nationality, and education constitute different gendered subject positions, and that different constellations provide different inroads to interview situations.
} 


\section{Destabilising the 'heterosexual couple' in the space of commercial sex by night}

The following example is taken from an ordinary Thai bar, which is a well-known place in the Thai migrant community. Primarily, it is a meeting place for two social groups of guests: female Thai migrants and Danish men who relate to the Thai migrant community through marriage, longer and shorter relationships and/or take interest in Thailand by frequent holidays in Thailand. Moreover, it is also a place where concealed sex work takes place.

At night, sexual identity came into play during our visits at the bars. As Coffey (2005: 410) notes, our (the researchers') "sexuality, emotional and physicals desires do not disappear on entering the field". According to Coffey, sexual identity can affect the process of undertaking participant observations. For example, she underscores that the marital status of female anthropologists has affected their access to the field (ibid.: 412). In the case of my participant observations, sexual identity did come into play. Inspired by Butler's ${ }^{4}$ (1990) concept of gender, the components of sexual desire, sexual practices, body and social gender are relevant in the process of establishing field relations. Through these field relations gender hierarchies are established and negotiated.

One of the evenings at the ordinary bar we meet Alicia. Niels has met her before in the nightlife. He tells me that she has up to several times made a pass on him. Niels assesses that she could be a relevant interviewee.

Alicia is rather tall (at least 1.80 meters) and slim with long dark brown reddish hair wearing a tight-fitting red miniskirt, shining high-heeled sandals and a top. She is transgendered from a male subject to a female subject. When Alicia sees us, she heads for our table gives Niels a hug, talking loud and kisses me on the cheeks. Then she looks me straight in the eyes saying: "You are beautiful, but not sexy!". Niels introduces Alicia to me in English, asking her for an interview. She does not answer him directly in English, but in Thai she suggests that he spends a night with her. This he refuses in a polite way. Five minutes later she leaves us to talk with some other (male) guests. After discussing which approach we should use to approach Alicia, we agree that I should ask her for an interview without Niels' assistance. Alicia sits between two men on a sofa, chatting when I address her asking if she has two minutes to talk in private. Smiling, she accepts. Outside the bar I present my project briefly, asking if she is willing to do an interview about her life in Denmark and her views on gender and sexuality. Without hesitating she accepts and we arrange an interview meeting.

The week after, I conduct an interview with Alicia. As agreed with Alicia, Niels participates although we speak English. Openly, Alica tells me about how the Danish men she meets at the bars are attracted to her. Proudly, she tells me that every part of her body - face, legs, hips and hair - is natural, only the breasts are imitations. She explains to me that she defines herself as a woman, underscoring how the heterosexual men find her attractive and sexy as a woman. According to Alicia, the men particularly like the fact that she still has a penis. Suddenly, she interrupts herself. Addressing Niels, she says to him: "I like her (Marlene), she is nice". Thereafter, she continues telling me about her love life, femininity and the men.

In this field situation - meeting Alicia in the bar and asking her for an interview - gender performances and sexual identities are crucial in establishing field relations between the studied

\footnotetext{
${ }^{4}$ See also Spanger 2012 for an elaborating of Butler's (1990) concept of gender in relation to perceptions of the Thai migrants selling sexual services in Denmark.
} 
subject, the researcher and the research assistant. Niels and I represented a heterosexual couple at the bar, although we just related through our professional background as academics. This may have made it important to Alicia to position me as a non-sexual object, someone who could not threaten her position as an attractive woman in Niels' eyes by stating: "she is not sexy".

When speaking alone with Alicia, the gender hierarchy constituted by look, bodily practices and sexual desire disappear, as I am not a threat in terms of a potential rival. Rather, I am in an inferior position wanting something from her; namely her knowledge about gender, sexuality and migration, and I have nothing to offer in return (not a night with Niels either!). During the interview, I question Alicia about defining herself as a woman through bodily practices (adjusting the body), looks, sexual relations and belongings. There were no explicit openings for asking about selling sex. Presumably, I appeared as totally harmless not challenging her femininity or her probable concealed sex work, which is why she finds me nice. At the end of the interview, Niels takes over, asking about her knowledge about prostitution at the bar. Alicia's answers are now suddenly snappy and her flirting attitude towards Niels is gone.

Aiming to obtain narratives from the Thai migrant sex workers, I was situated in a rather powerless position compared to my research assistant, who could approach the female migrants quite easily. However, it was different in the case of Alicia. In the attempt to establish contact with Alicia with assistance from Niels, I was at first sight positioned as powerless due to us appearing to be a heterosexual couple. Without Niels' presence, it was much easier to establish contact with Alicia. Thus, power relations were constantly at play during my fieldwork. However, being in a powerless position was not always a disadvantage for me when gaining access to the narratives of the female migrants selling sexual services. I will elaborate on this in the following example.

\section{Negotiating femininity at Kulap's massage parlour}

The following narrative is an example taken from my visit to a massage parlour that clearly demonstrates how looks and bodily appearances, those of the female Thai migrant sex workers and myself respectively, constituted hierarchies of power relations based on the intersection of gender, sexuality, race and nationality.

Besides selling sex, Kulap is in charge of the massage parlour. Two female Thai migrants work there. They are asleep when I arrive around noon. Today, two friends, Lee Ann and Soi, are visiting Kulap, too. Often they drop by to play cards, watch Thai films and eat together. They both have a past in the sex industry working as escorts and at a strip bar. All the migrants are in their 30s. During my visit, I experience that appearance and bodily practices very much preoccupy Kulap and her two friends in their everyday lives. Kulap is quite stocky and small compared to her guests who are tall and slim. During Lee Ann's and Soi's stay at the massage parlour, they regularly check and adjust their make-up and clothes, which reflects how much effort they put into their looks. Right at the beginning of my visit, Lee Ann gives me a puzzled look, unsure of my country of origin due to my look and my Danish language. She has difficulties positioning me. Perhaps my clothes underscored her bewilderment. During my participant observations both during the day and at night, I was wearing buttoned-up shirts or a sweater and no flashy make-up or high heels. Lee Ann states that Kulap and I do not look like Thais with our small eyes, round faces and light skin, rather we look Japanese or Chinese. Such statements constitute difference based on a power hierarchy established by race and gender. I tell her that I am adopted from Korea and have lived all my life in Denmark, and that I am at the moment doing a study on Thai migrants selling sex in Denmark, focusing on their migration 
and their everyday lives in Denmark. Like Lee Ann and Soi, Kulap seems very aware of how femininity is performed through their appearance and bodily practices. At Kulaps' place, looks and bodily practices are ascribed crucial meaning in defining femininity.

During our conversation, Lee Ann brings up the issue of beauty and being attractive in between my questions. Kulap says to me: "You see how good-looking Lee Ann is!" She repeats this several times during my visit, complimenting the body and face of Lee Ann. During the interaction and dialogue at the massage parlour, Kulap reproduces the hierarchy suggested by Lee Ann which positions Kulap in an inferior position to Lee Ann. By doing so, Kulap's exaggerated statement signals an acceptance of Lee Ann's self-understanding as a beautiful woman. In this way, Kulap creates a balance in negotiating femininity between her and Lee Ann.

Both Lee Ann and Soi are transgendered persons (m-t-f). Very proudly, Lee Ann explains to me how she underwent surgery. Every part of her body and face has been adjusted, and Kulap explains to me that not all men can see and feel that Lee Ann is transgendered. On the one hand, such a statement reflects again Kulap's inclusion of transgendered women and being loyal towards other Thai migrants representing the sex industry. On the other hand, being positioned in an inferior position as less beautiful due to her Asian look by Lee Ann, Kulap strikes back: grounded in a heteronormative discourse, where gender is determined by the components of the body (biology, surface and looks), sexual desire and sexual practices, Kulap emphasises that Lee Ann is not a 'natural woman' stating: "not all men can see and feel". By doing so, Kulap positions Lee Ann in an inferior position, despite her avowedly ideal look.

In the meantime, Soi has changed clothes from pants and a shirt to a dress that she has just bought and which could very easily be taken for a petticoat. Now she is lying sprawled on the sofa watching a Thai film. During my talk with Lee Ann and Kulap about their lives, Lee Ann suddenly sits down on Soi's sofa and just for fun puts her arm around her, catching one of her breasts and stating with a laughing voice, "She has coconuts" - the breast does not move at all when Lee Ann squeezes it. Soi just smiles, ignoring her, and continues to watch the Thai film. Before lunch, Lee Ann puts on more make-up, foundation and eye shadow. One of the sex workers, who were sleeping when I came, is awake. Looking at her, Lee Ann suddenly tells me that this female Thai migrant and I have the same hair structure - thick, dry and frizzy! I look at the woman. Lee Ann continues to tell me that she used to have the same hair structure, but after a treatment with a Thai hair product, her hair became soft and not so bristle and frizzy. A little confused about her change of subject, I compliment her hair structure, and continue to ask about her former work at the bar. Accepting her sudden statement and complimenting her hair structure I position myself in an inferior position, which I am quite aware of. Doing so is my way to ensure that the dialogue between me and Lee Ann continues.

Accepting a more inferior position, based on the intersecting hierarchies of gender, sexuality, race and nationality, among the female Thai migrants at the massage parlour was a way for me to signify that I was not a threat to how they perform femininity. It was a strategy to gain their confidence and to be accepted, which I hoped meant that I obtained insights into how they perform gender within the space of commercial sex.

Commenting on my look - the frizzy hair, small eyes and round face - and positioning me as Chinese or Japanese in relation to the Thai migrants at the massage parlour, different gendered and racialised positions are established through the looks and bodily practices. This makes it 
possible for me to analyse how they perform gender, as well as gain insight into their notions of ideal femininity within the space of commercial sex. Furthermore, a central gendered demarcation between female-born persons and transgendered persons $(\mathrm{m}-\mathrm{t}-\mathrm{f})$ is drawn during my visit. At the same time, Lee Ann establishes a hierarchy between her and the other transgendered woman, Soi, based on their adjustment of the body. Demonstrating the stiffness of Soi's breast by squeezing it, and at the same time emphasising that the men cannot see or feel that her body has been adjusted, she positions Soi in an inferior position based on the discourse of the natural body. Positioning Lee Ann as 'beautiful', Kulap reaffirms a heterosexual gender hierarchy, where Lee Ann represents the ideal of femininity. This hierarchy intersects with a racial hierarchy, and reflects how processes of identifying and not-identifying subject positions take place. Positioned as representing ideal femininity, having a reorganised face constructed to be a more white feminine face (larger nose, eyes constructed as Caucasian eyes and an ovalshaped face), Lee Ann also reproduces a racial and gendered hierarchy by, stating that Kulap and I look more Chinese or Japanese, which in this case positions us as inferior to white femininity.

Having no education, working in the sex industry, and having difficulties speaking the majority language (Danish), the Thai migrants at Kulap's place could easily be positioned as inferior to me, who represents a well-educated 'female-born' woman who also represents a wellintegrated ethnic minority group as a transnational adoptee speaking fluent Danish. However, being aware of me as an outsider visiting their space (of commercial sex), Kulap and Lee Ann's negotiation of appearance, looks and bodily practices can be viewed as a way to gain dignity and create a power balance between the studied subjects and the researcher. Moreover, when Kulap says, "You see how good-looking Lee Ann is!" it can also be interpreted as a way of recognising her femininity.

The ongoing negotiation among female Asians (including me), based on gender, sexuality, nationality and race, establishes a racialised heterosexual gender hierarchy, and disrupts the dichotomy of 'the victimised prostitute' versus 'the empowered sex worker'.

\section{Conclusion}

I have demonstrated how looks and bodily practices become important in establishing field relations between the researchers and the migrant sex workers. These field relations, constituted by intersecting gendered and racialised hierarchies, formed the basis for producing material for my study of female Thai migrants selling sexual services.

Positioned as inferior within such a racialised heterosexual gender hierarchy has both been an advantage and a disadvantage to me during the participant observations. In some situations, it was a disadvantage as I was dependent on Niels to establish contact with the Thai migrants. On the other hand, the inferior position facilitated insight into the competition in performing femininity between female-born subjects and transgendered subjects among female Thai migrant sex workers in Denmark (Spanger, 2012). The different constellations of subject positions depended on specific locations and times, in this case, at bars at night or at massage parlours during the day. In particular, I was positioned as powerless in terms of establishing contact with the migrants in different ways, depending on the research location. Being an Asian adoptee, but not identifying myself as Thai, and sometimes being assisted by a young white Danish man speaking Thai, such constellations of subject positions resulted in my increased awareness of how the informants ascribed meaning to bodily practices and looks through the categories of gender, race and nationality, and how they narrated their gendered and sexual 
practices. From a poststructuralist feminist approach (Butler, 1990; Haraway, 1991; Lather, 2000; Haavind, 2000) this reflects how they construct and negotiate various subject positions that transgress and disrupt the fixed subject positions of the 'victimised prostitute' or 'the empowered sex worker', and thus question the prevalent dichotomous thinking within studies on transnational prostitution. Disrupting the dichotomy is a way to overcome the reproduction of the fixed 'bad/good' subject positions that spring from the discourse of prostitution/sex work, and which simplifies the narratives about these Thai female migrants' everyday lives.

\section{Acknowledgements}

I am grateful to PhD Fellow Kristian Fahnøe, Roskilde University, Denmark, for highly constructive and careful feedback on former versions. I would also like to thank the editors and the anonymous reviewers for their commentary on the manuscript.

\section{References}

Agustín, L. M. (2005). The Cultural Study of Commerical Sex. Sexualities, 8 (5): 618-631.

Archer, L. (2002). "It's easier that you're a girl and that you're Asian": Interactions of 'race' and gender between researchers and participants. Feminist Review, 72, 108-132.

Aoyama, K. (2009). Thai Migrant Sexworkers. From Modernisation to Globlisation. New York: Palgrave Macmillan.

Butler. J. (1990). Gender Trouble. Feminism and the Subversion of Identity. London and New York: Routledge.

Chapkis, W. (1997). Live Sex Acts: Women Performing Erotic Labor. New York: Routledge.

Coffey, A. (2005). The Sex(ual) Field. In C. Pole (ed.), Fieldwork. Origins and Definitions of Fieldwork, Vol. I. London: Sage Publications.

Davidson J. O. (1998). Prostitution, Power and Freedom. Cambridge: Polity Press.

Davidson J. O. and Taylor, J. (1999). Fantasy Islands: Exploring the Demand for Sex Tourism. In K. Kempadoo (ed.), Sun, Sex and Gold. Tourism and Sex Work in the Caribbean. Boulder: Rowman and Littlefield Publishers.

Doezema, J. (1998). Forced to Choose: Beyond the Voluntary v. Forced Prostitution Dichotomy, in K. Kempadoo and J. Doezema (eds.) Global Sex Workers: Rights, Resistance, and Redefinition. New York: Routledge.

Haraway, D. (1991). Simians, Cyborgs, and Women. The reinvention of Nature. London: Free Association Books.

Hasse, C. (2000). Overvejelser om positioneret deltager-observation. Sexede astronomer og kønnede lærerprocesser. Kvinder, Køn \& Forskning, 9 (4): 39-51.

Haavind, H. (2000). Kjønn som fortolkende metode. Metodiske muligheder i kvalitativ forskning. Oslo: Gyldendal Norsk Forlag. 
Kempadoo, K. et al (2005). Trafficking and Prostitution Reconsidered. New Perspectives on Migration, Sex work, and Human Rights. Boulder and London: Paradigm.

Lather, P. (2000). Against empathy, voice and authenticity. Kvinder, Køn \& Forskning, 9 (4): 16-25.

Lather, P. (1986). Research as Praxis. Harvard Educational Review, 56 (3): 257-277.

Lykke, N. (2008). Kønsforskning. En guide til feministisk teori, metodologi og skrift. København: Forlaget Samfundslitteratur.

Nencel, L. (2001). Ethnography and Prostitution in Peru. London: Pluto Press.

Petersen, L. M. (2009). Adopteret - fortxllinger om transnational og racialiseret tilblivelse. Ph.d.afhandling, Institut for Læring, DPU. Aarhus Universitet.

Pheterson, G. (1996). The Prostitution Prism. Amsterdam: Amsterdam University Press.

Phoenix, A. (2006). Interrogating intersectionality: Productive ways of theorising multiple positioning. Kvinder, Køn \& Forskning, 15 (2-3): 21-31.

Reeves, C. L. (2010). A difficult negotiation. Fieldwork relations with gatekeepers. Qualitative Research, 10 (3): 315-331.

Sanders, T. (2006). Sexing Up the Subject: Methodological Nuances in Researching the Female Sex Industry. Sexualities, 9 (4): 449-468.

Sanghera, G. S. and S. Thapar-Björkert. (2008). Methodological dilemmas. Gatekeepers and positionality in Bradford. Ethnic and Racial Studies, 31(3): 543-562.

Shaver, F. (2005). Sex Work Research: Methodological and Ethical Challenges. Journal of Interpersonal Violence, 20 (3): 296-319.

Spanger, M. (2001). Mellem anonymitet og synlighed. Om sorte kvinders transnationale prostitution i Danmark. Kvinder, Køn \& Forskning, 10 (3): 48-60.

Spanger, M. (2010). Destabilising Sex Work \& Intimacy? Gender Performances of Female Thai Migrants Selling Sex in Denmark. Department of Society and Globalisation, Roskilde University.

Spanger, M. (2011). Human Trafficking a Lever for Feminist Voices? Transformations of the Danish Policy Field of Prostitution. Critical Social Policy, 31 (4): 517-539.

Spanger. M. (2012 forthcoming). Gender Performances as Spatial Acts: (Fe)male Thai Migrant Sex Workers in Denmark, Gender, Place and Culture.

Søndergaard, D. M. (2002). Poststructuralist Approaches to Empirical Analysis. International Journal of Qualitative Studies in Education, 15 (2): 187-204.

Testaì, P. (2008). Debt as a Route to Modern Slavery in the Discourse on 'Sex Trafficking': Myth or Reality? Human Security Journal, 6 spring: 68-77. 
Yuval-Davis, N. (2006). Belonging and the Politics of Belonging. Patterns of Prejudice, 40 (3): 197214.

Author

Marlene Spanger is Assistant Professor at the Department of Culture and Global Studies, Aalborg University, Denmark. Email: spanger@cgs.aau.dk 